\title{
ENTREPRENEURSHIP IN GERMANY AND THE ROLE OF THE NEW SELF-EMPLOYED
}

\author{
Herbert Grüner \\ Berlin University of Applied Sciences (Fachhochschule für Technik und Wirtschaft), \\ E-mail: herbert.gruener@fhtw-berlin.de
}

Received 2010 2005; accepted 20012006

\begin{abstract}
In the following article we show the meaning of entrepreneurship and self employment for the German economy after the reunification. We flashlight the German founding boom since 2003, as new labour market policy instruments have been developed and financed. On the basis of three regional investigations we compared the new self-employed according to: social and vocational-biographical development, motivation and nature of business founded, founding qualifications and qualification strategies.
\end{abstract}

Keywords: new self-employed, Ich-AG, self employment, labour market policy, German founding boom, necessity founders

\section{The meaning of entrepreneurship and self- employment for the German economy}

Reunified Germany is one of the most developed countries in the world with a gross value added of $2003,18$ billion Euros (in 2004) $)^{1}$ and a real gross domestic product (GDP) of over 30,000 USD per person per year [1]. Similarly, integration in transnational trade relations is very advanced. The German export economy has developed particular strength. Despite all of this, over the last ten years economic growth in Germany has lagged notably behind other economies those of other EU countries for example. This has resulted in increased unemployment, which, although it fell in summer 2005, remains at a high level and, as before, differs greatly between the east and west of Germany [Fig 1].

The slight fall in unemployment in summer 2005 is, however, the result of season variation. Structural unemployment has remained at virtually the same level

${ }^{1} \mathrm{cf}$. http://www.destatis

\begin{tabular}{|c|c|c|c|}
\hline & Total & New States & Old States \\
\hline $\begin{array}{c}\text { Unemployment, } \\
\text { April 2005² }\end{array}$ & $12.0 \%$ & $19.7 \%$ & $9.9 \%$ \\
\hline $\begin{array}{c}\text { Unemployment, } \\
\text { Juni 2005 }\end{array}$ & $\begin{array}{c}4,704,000 \\
\text { Persons } \\
11,3 \%\end{array}$ & $\begin{array}{c}1,587,000 \\
\text { Persons }\end{array}$ & $\begin{array}{c}3,117,000 \\
\text { Persons }\end{array}$ \\
\hline
\end{tabular}

Fig 1. Unemployment in Germany - differentiated between new (i.e. eastern) and old (i.e. western) German states, second quarter $2005[2,3]$

for a substantial period of time. Structural changes as the trigger for unemployment are detectable not only in Germany, but in all industrially advanced countries in the western world. The scope and speed of structural and procedural changes in business have significantly increased over the past years, and Germany is additionally being affected by a transition process: the process of transformation from a command economy to a market economy in the new German federal states. The economic consequences of this rapid

\footnotetext{
${ }^{2}$ cf. Hartmann, M., 2005, p. 168

${ }^{3} \mathrm{cf}$. www.arbeitsagentur.de
} 
transformation included conversion of state-owned enterprises into privately owned companies, plant closure and the formation of new companies, and the necessity for many employees to switch to different occupations or places of work or to lose their jobs. The current, above-average rate of unemployment in the new German federal states indicates that this transformation process still has some way to go.

Ways out of Germany's economic crisis are being sought on the one hand through the introduction of increased flexibility within the field of employment, and on the other through more self-employment and an increase in the number of new businesses founded. Entrepreneurship, in terms of founding businesses, is connected with a range of preferences grouped on the hand one around the aim of creating more (future) jobs, and on the other around the aim of effecting technology transfer. To unify both groups, two factors must be present - firstly, persons possessing an appropriate and relevant training qualification must be available and secondly, they must be in the position to be able to found a successful business.

In Germany in 2003, 36,172 million people were gainfully employed, 3.74 million of them being selfemployed. If the employed in Germany are examined according to the nature of their work, we see the following Fig 2.

\begin{tabular}{|c|c|c|}
\hline $\begin{array}{c}\text { Nature of } \\
\text { employment }\end{array}$ & $\begin{array}{c}\text { \% of gainfully } \\
\text { employed } \\
\text { persons - April } \\
1991\end{array}$ & $\begin{array}{c}\text { \% of gainfully } \\
\text { employed } \\
\text { persons - May } \\
2003\end{array}$ \\
\hline Self-employed & 8.1 & 10.3 \\
\hline $\begin{array}{c}\text { Assisting family } \\
\text { member }\end{array}$ & 1.4 & 1.1 \\
\hline $\begin{array}{c}\text { Salaried } \\
\text { employee }\end{array}$ & 44.9 & 51.5 \\
\hline $\begin{array}{c}\text { 'Blue Collar' } \\
\text { employee }\end{array}$ & 38.9 & 30.9 \\
\hline State employee & 6.7 & 6.2 \\
\hline
\end{tabular}

Source: Statistisches Bundesamt, 2004, p. 68 [4]

Fig 2. Self-employment and conventional employment in Germany in 1991 in comparison to 2003

Parallel to the labour market, the entrepreneurial situation in Eastern and Western Germany differs, too. The activity and attitude towards entrepreneurship (setting up an SME) is subdivided in Eastern and Western Germany (Fig 3).

Analogous to the situation of registration and closedown, the number and the rate of self-employed/

\begin{tabular}{|c|c|c|}
\hline & $\begin{array}{c}\text { Old German } \\
\text { federal states }\end{array}$ & $\begin{array}{c}\text { New German } \\
\text { federal states }\end{array}$ \\
\hline $\begin{array}{c}\text { Registration in } \\
\text { total }\end{array}$ & 617,439 & 105,894 \\
\hline $\begin{array}{c}\text { Close down in } \\
\text { total }\end{array}$ & 141,086 & 36,634 \\
\hline $\begin{array}{c}\text { Registration per } \\
1,000 \text { residents }\end{array}$ & 9.05 & 7.73 \\
\hline $\begin{array}{c}\text { Close down per } \\
1,000 \text { residents }\end{array}$ & 2.14 & 2.59 \\
\hline
\end{tabular}

Source: Statistisches Bundesamt, 2003 [5].

Fig 3. Registration and close down of trade or business in 2002

entrepreneurs among the workforce is smaller in the new German federal states than in the Western part of the country Fig 4.

In general, the economic situation in eastern Germany is less entrepreneurial than in western Germany, measured by the number of SMEs, start-ups and selfemployed persons/entrepreneurs. This phenomenon can be attributed to a number of reasons resulting from the very different situations in the 16 federal states after the reunification: different experience with market economy, different demands, buying and consuming habits, spending power or chances to receive venture capital. But also the attitude and mentality seems to be different. The research results show that persons in eastern Germany are more afraid of failing with a start-up than persons in Western Germany.

The Global Entrepreneurship Monitor, which covers 34 countries $^{4}$ [7], makes possible an assessment of the development of self-employment in Germany as a whole when compared internationally. This assessment clearly shows that Germany - measured in terms of self-

\begin{tabular}{|l|c|c|}
\hline & $\begin{array}{c}\text { Old } \\
\text { German } \\
\text { federal } \\
\text { states }\end{array}$ & $\begin{array}{c}\text { New } \\
\text { German } \\
\text { federal } \\
\text { states }\end{array}$ \\
\hline $\begin{array}{l}\text { Number of self- } \\
\text { employed/entrepreneurs }\end{array}$ & $2,857,000$. & 96,100 \\
\hline $\begin{array}{l}\text { Rate of self- } \\
\text { employed/entrepreneurs }\end{array}$ & 9.9 & 7.7 \\
\hline
\end{tabular}

Source: Biersack/Parmentier/Schreyer, 2000, p. 6, 25, 107, 459 [6].

Fig 4. The number and rate of self-employed/entrepreneurs in Germany

${ }^{4}$ cf. Sternberg/Lückgen, 2005. 
employment and / or rates of start-ups - can on no account be considered particularly active where the founding of new businesses is concerned. Current reports from each state for 2004 demonstrate that Germany occupies place 19 of 34 countries assessed in terms of the proportion of adults who had founded a business by the middle of 2004. For the statistic "Adults who have recently founded a business or intend to do so", German lies at 24; in terms of its quota of young businesses, at $20^{5}$ [8]. The implementation of an idea for a business appears comparatively more difficult in Germany, although start-ups with strong growth represent one of Germany's strengths.

\section{The new self-employed as a result of labour market policy measures}

The structural changes introduced to western countries, and given an extra boost in Germany through the process of reunification, have had marked effects on the labour market and situation of its dependent workforce. To combat the unemployment resultant of these factors, Germany introduced a legislative initiative at the end of the 2005 legislative period in order to bring more unemployed people, together with those threatened with unemployment, into gainful employment. One aim of this initiative is to convert formerly employed persons into self-employed persons. In the following, these are referred to as the "new selfemployed". In Germany, the term Ich - AG (roughly equivalent to the English "Me PLC") has become commonplace. It designates self-employed persons who in the main part have founded one-person businesses with the help of state-sponsored benefits.

One of the actions resultant of the German government's innovation initiative "Agenda 2010 Deutschland bewegt sich"6 ("Agenda 2010 - Germany on the move"), has been the implementation of legislative measures concerning labour market modernisation (the so-called "Hartz"7 laws). The "Existenzgründungszuschuss" (start-up grant) benefit programme was developed by the so-called "Hartz Kommission" (Hartz Commission), and is known as the Ich - AG. The introduction of the Ich - AG aims in principle to reduce unemployment, but also to decrease illegal work and associated tax fraud. As from 1.

\footnotetext{
cf. Sternberg/Lückgen, 2005, p. 6 .

Presse- und Informationsamt der Bundesregierung, 2004.

The proposals stemmed in the main part from the 15 person commission named after chairman Hartz (currently a member of the Volkswagen concern's management board), formed by the government under Chancellor Gerhard Schröder to implement the 2002 Agenda 2010 reforms.
}

January 2003, persons who end a period of unemployment by becoming self-employed are entitled to a monthly start-up grant. ${ }^{8}$ This grant is paid for a period of up to three years, and is subject to approval at least once a year. It comprises 600 Euros per month in the first year, 360 Euros in the second and 240 Euros in the third. The benefit is only eligible for persons aged under 65. After the business has been founded, predicted income may not exceed 25,000 Euros annually. The legislation passed at that start of 2003 has been modified in two points: a ban on hiring employees has been lifted (July 2003), and a further condition for receiving the grant has been introduced from January 2005 a business plan must have been created. The Ich - AG founder must have the feasibility of his or her business concept confirmed by an "informed advisor". ${ }^{9}$ Various forms of industry-, salesand trade associations and organisations as well as credit institutes are recognised as informed advisors. Prior to the introduction of this modification, the business plans of new business founders were not checked.

In comparison with the rather modest estimations of the Institute for Labour Market and Occupation Research (German: Instituts für Arbeitsmarkt- und Berufsforschung - IAB) ${ }^{10}$ in autumn 2002, this labour market policy aiming to raise self-employment has developed positively [9]. In the interim, support for self-employment has become a more significant factor within the federal employment agency's labour market policy. Since the introduction of the Ich - AG on 1 . January 2003, over 370,000 people have become selfemployed with the help of the start-up grant ${ }^{11}[10]$. As soon as the end of the first year (2003), $8 \%$ of those coming out of unemployment had taken up selfemployment, making use of the grant ${ }^{12}$ [11]. In January 2005, 239,100 Ich - AG entrepreneurs received support - a rise that, taken against the figure from January the preceding year, represents an increase of $120 \%{ }^{13}$ [12]. Both the so-called "start-up boom" of recent years and the rise in gainful

\footnotetext{
Legislative basis is $\S 421 \mathrm{I}$ of the third book of social law (German: Sozialgesetzbuch) last modified on 1.1.2005.

9 Federal Ministry for Economics and Employment (German: Bundesministerium für Wirtschaft und Arbeit), 2004, p. 18. The basis for the informed advisor's decision generally takes into account information regarding intentions and business ideas, $\mathrm{CV}$ incl. certificates of vocational competence, capital requirements and/or finance plans and a feasibility study (turnover, costs, expected profit).

10 cf. Institut für Arbeits- und Berufsforschung, 2002.

${ }^{11} \mathrm{cf}$. Bundesministerium für Wirtschaft und Arbeit, 2004, p. 6.

${ }^{12} \mathrm{cf}$. KfW Bankengruppe, p. 24.

${ }^{13} \mathrm{cf}$. Bundesagentur für Arbeit, p. 11f.
} 
employment have come about less for economic reasons than for the fact that they have been promoted through measures supporting start-ups ${ }^{14}$ [13]. The Centre for European Economic Research (German: Das Zentrum für Europäische Wirtschaftsforschung) takes the position that the start-up trends in the fields of trade, consumer services and construction in particular have been positively influenced by these labour market measures, noting that "founding a business in these areas is possible without specific qualifications" $^{15}$ [14].

\section{The new self-employed - development, motivation and qualification strategies}

The Ich - AG and its founders have not yet been the subject of comprehensive research. The following findings originate from three region investigations carried out between April 2003 and October 2004. These consisted chiefly of an examination coordinated by the "Institut für Mittelstandforschung (IfM)" (Institute for Small and Medium Businesses Research) and the "Gesellschaft für innovative Beschäftigungsförderung mbh (G.I.B.)" (Organisation for Innovative Employment Support), who distributed questionnaires to unemployed persons or those threatened by unemployment in the German state of North Rhein Westphalia ${ }^{16}$ [15]. From 1,116 potential Ich - AG founders who took part in the orientation seminars of this organisation, $51 \%$ (567 persons) agreed to take part in the investigation. The investigation's coordinators point out that the results could be influenced by "positive selection"17. The second study was carried out by the agency for the creation of new businesses in collaboration with employment agencies in Munich, Freising and Weilheim ${ }^{18}$. From 2,996 founders from the three districts who had applied for financial support for new businesses, 1088 (returns quota $36.3 \%$ ) took part. The third study was commissioned by the "Hannover Industrie- und Handelskammer" (Hannover Industry and Trade Professional Association) in collaboration with
Hannover employment agency and carried out by the Hannover University for Applied Sciences ${ }^{19}$ [16]. This final investigation involved distributing questionnaires to founders and / or persons, who have founded a firm and have already employed staff. 2,000 sets of data were recorded, half returned to the IHK Hannover (commercial business registrations), half to the Hannover employment agency (the agency responsible for temporary financial support and financial support for founding businesses). The return quota was $8.85 \%$ (a total of 177 returns, 48 thereof from Ich - AG companies $)^{20}$.

\subsection{Social and vocational-biographical development}

The majority of the founding persons questioned by the BfE are female $(57.4 \%)$, with German nationality $(86.9 \%)$ and an average age of $38.8^{21}$. These findings correspond broadly with those gained from the potential founders questioned by G.I.B./IfM. Here, the proportion of foreigners is also very small $(6.5 \%)$, while the average age is $40.6^{22}$. The proportion of women is, however, slightly lower when compared with the study referred to above, at $47.9 \%{ }^{23}$. Like both of the above studies, the overwhelming majority of founders in the Hannover investigation were also of German nationality $(93.2 \%)^{24}$. The average age of Ich - AG entrepreneurs was 40, the proportion of women $48.9 \%{ }^{25}$. According to the BfE investigation, just over every fourth Ich - AG entrepreneur lives in a one-person household, the majority occupying multiple-person households $(71.8 \%)$ with an average occupancy of 2.4 persons $^{26}$. A total of $47.1 \%$ of the Ich - AG entrepreneurs questioned by BfE are the main earners in their household. For those living with others, however, this proportion falls to $26.5 \%{ }^{27}$. The B.I.G/ IfM study showed that two out of three Ich - AG founders $(66.9 \%)$ are married or live within a civil union. $42.3 \%$ of this group have children requiring maintenance. The majority of Ich - AG founders have access to a second household income (59.9\%). This

\footnotetext{
${ }^{14}$ cf. KfW Bankengruppe, 2004, p. 8 und p. 23. Bürgschaftsbank zu Berlin-Brandenburg, 2005, p. 1-5. Zentrum für Europäische Wirtschaftsforschung, 2004, p. 1. Bundesagentur für Arbeit, 2005, p. 2.

15 cf. Zentrum für Europäische Wirtschaftsforschung, 2004, p. 1.

16 cf. Kleinen, H./May-Strobl, E./Suprinovic, O./Wolter, H.-J., 2004.

17 Kleinen, H./May-Strobl, E./Suprinovic, O.(Wolter, H.-J., 2004, p. 9.

18 cf. Büro für Existenzgründungen (BfE), 2004.

19 Wuttke, J., 2004.
}

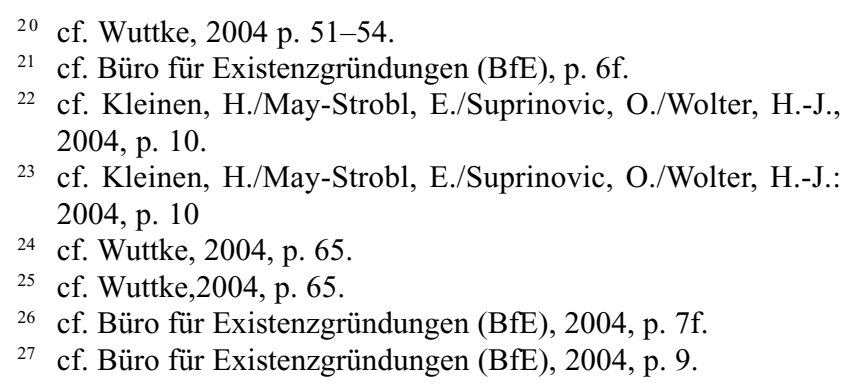


is significantly more often the case amongst women than amongst men $(73.5 \% \text { to } 47.3 \%)^{28}$. Single persons also represent a minority in the Hannover study; around two thirds are married or attached to long-term partners ${ }^{29}$. The data relating to employment and biographical history show that the majority of (potential) Ich - AG founders have completed a vocational training programme and have a relatively high level of formal education. $69 \%$ of those questioned by the BfE had attained a vocational qualification, 5.6\% at an advanced level. Approx. $25 \%$ of participants had gained a degree from a university or a university of applied science. Only $8.5 \%$ of those questioned had no vocational qualifications at the time the survey was carried out ${ }^{30}$. The G.I.B./IfM survey offers similar results. Virtually none of the participants lacked a school leaving certificate $(0.7 \%)$, while $43.7 \%$ had completed their "Abitur" (German " $\mathrm{A}$ " Level equivalent). 21.8\% of the founders questioned had a degree, $3.5 \%$ an advanced level vocational qualification and $82.4 \%$ a standard vocational qualification (multiple answers were possible $)^{31}$. Persons lacking a completed vocational qualification were a minority $(12.0 \%)$. Of the Ich AG founders surveyed in Hannover, persons with "Abitur" dominated, followed by those with a standard comprehensive school leaving certificate ${ }^{32}$. In terms of vocational education, the majority of participants had completed an apprenticeship (51.8\%), the next largest group being those with a university degree $(28.6 \%)^{33}$. The Hannover study was not able to present information regarding work experience in various fieldsHHH ${ }^{34}$. Regarding the time span prior to the founding of an Ich - AG or prior to taking the first steps towards self-employment, the B.I.G./IfM study indicates that founders generally come from a state of unemployment averaging approx. 15 months. The average unemployment benefit received during this period was 557 Euros a month. Added to this it is clear that a notable proportion of future Ich - AG entrepreneurs were employed part-time prior to unemployment $(26.1 \%)$. It could also be seen from the

28 cf. Kleinen, H./May-Strobl, E./Suprinovic, O./Wolter, H.-J.,2004, p. $10 \mathrm{f}$.

29 cf. Wuttke, 2004, p. 66.

30 cf. Büro für Existenzgründungen (BfE), 2004, p. $9 f$.

31 cf. Kleinen, H./May-Strobl, E./Suprinovic, O./Wolter, H.-J., 2004, p. $11 \mathrm{f}$.

32 Proportion of those with "Abitur": $39,6 \%$, proportion of those with comprehensive school leaving certificate: $33,3 \%$. All persons possessed a certificate of formal schooling. Source: cf. Wuttke, 2004, p. 67.

${ }^{33} \mathrm{cf}$. Wuttke, 2004, p. 69.

${ }^{34} \mathrm{cf}$. Wuttke, 2004, p. 70.
BfE results that the majority of participants had received unemployment benefit immediately before founding an Ich - AG (83.7 \%).

$18.3 \%$ of those questioned were unemployed for a period of more than 12 months ${ }^{35}$. Just over two thirds of participants had a total monthly income of 800 Euros or less. The average duration of unemployment for founders in the Hannover study was 11.6 months ${ }^{36}$.

\subsection{Motivation and nature of business founded}

To determine their motivation, potential Ich - AG entrepreneurs were presented with statements with which they should agree or disagree (in the studies from BfE and Hannover) or rate in terms of their significance on a scale of 1 to 5, 1 being "very important", 5 being "completely irrelevant" (in the G.I.B./IfM studies). The G.I.B./IfM surveys make clear that the fundamental motivation for the founding of an Ich -AG is that it offers an escape from unemployment. Two thirds of participants rated this reason as very important. This motivation correlates with age, length of time spent unemployed and level of education: the older the participants, the longer the duration of their unemployment and lower their level of formal education, the more often that the Ich - AG is the motivating force for founding a business ${ }^{37}$. Alongside this motivational factor (average value 1.59), achieving economic independence (average value 1.86) and increased self-determination (average value 1.96) represented the next most important motivation for founding an Ich - AG. The improved compatibility of family and occupation through self-employment only registered a medium value in terms of motivation (2.35). Social status is also a comparatively insignificant motivational factor (average value 3.31). The BfE questionnaires show that the vast majority of participants would have preferred a permanent position to self-employment, only $15 \%$ stating the opposite ${ }^{38}$. A significant factor for most of those questioned (around three quarters) was the prospect of receiving financial support. $10.7 \%$ would "definitely not" and $41.5 \%$ would "probably not" have become selfemployed without financial support available for founding a business ${ }^{39}$. Nevertheless, $29.7 \%$ of the

\footnotetext{
${ }^{35} \mathrm{cf}$. Büro für Existenzgründungen (BfE), 2004, p. 15f.

${ }^{36} \mathrm{cf}$. Wuttke, 2004, p. 71.

${ }^{37}$ cf. Kleinen, H./May-Strobl, E./Suprinovic, O./Wolter, H.-J, 2004, p. $13 f$.

${ }^{38}$ cf. Büro für Existenzgründungen (BfE), 2004, p. 18.

${ }^{39} \mathrm{cf}$. Büro für Existenzgründungen (BfE), 2004, p. 22.
} 
participants stated that "It (was, HG) always my dream to become self-employed" 40 . The improved compatibility of family and occupation through selfemployment was quoted by $59 \%$ of the Ich - AG entrepreneurs as a motivational factor. In the group of Ich - AG founders from Hannover, by far the most dominant motivational aspect was "an escape from unemployment" followed by the factor "improved professional development potential". Social status, in contrast, was considered the least significant motivational aspect ${ }^{41}$. The majority of the Hannover sample regarded self-employment as very convenient or convenient for their private lives ${ }^{42}$.

In terms of the nature of the businesses founded, the G.I.B/ifM study was dominated by the service sector, while businesses involved in production were markedly less significant ${ }^{43}$. The proportions of services for people (26.1\%) and services for business (23.9\%) are evenly balanced. To be noted is the relatively high proportion of freelancers within Ich - AG businesses (36.6\%). Those questioned in the G.I.B./IfM survey generally based their businesses on their own ideas (80\%), although the application of ideas stemming from their own area employment was extremely rare $(3.5 \%)^{44}$. Every third person questioned possessed no experience of the field of work they pursued in self-employment, nor of the work itself. As a rule, the Ich-AG entrepreneurs surveyed run their businesses alone $(93.2 \%)$ and only expected low positive net incomes in the first year of operation. A minority planned to hire personnel $(20 \%)$. The average requirement in terms of capital to start in self-employment is relatively low $(4,000 \text { Euros on average })^{45}$. Around two thirds of the Ich - AG entrepreneurs surveyed in the BfE study perform services; this group comprises more women than men $(74.6 \% \text { to } 54.9 \%)^{46}$. As in the G.I.B/IfM study, the industrial sector also assumes very low significance in the BfE survey $(0.6 \%)$. In their selfemployment, about half of the founders apply experience gained from their previous employment or

\footnotetext{
${ }^{40}$ Büro für Existenzgründungen (BfE), 2004, p. 18.

${ }^{41}$ cf. Wuttke, 2004, p. 79.

${ }^{42} 20.8 \%$ and $35.4 \%$ respectively, evaluated with a 1 or 2 on a scale of 1 (very positive) to 5 (very negative. Source: Wuttke, 2004, p. 61

43 cf. Kleinen, H./May-Strobl, E./Suprinovic, O./Wolter, H.-J, 2004, p. $17 f$.

${ }^{44}$ cf. Kleinen, H./May-Strobl, E./Suprinovic, O./Wolter, H.-J, 2004, p. $19 f$.

${ }^{45}$ cf. Kleinen, H./May-Strobl, E./Suprinovic, O./Wolter, H.-J, 2004, p. 19.

${ }^{46}$ cf. Büro für Existenzgründungen (BfE), 2004, p. 12.
}

its field ${ }^{47}$. The Ich - AG businesses examined in the BfE study are almost always run by one person $(92.1 \%)$. Only $17.3 \%$ of those surveyed by the BfE stated that the income from their self-employment was sufficient. This proportion is considerably smaller amongst women than men $(14.4 \% \text { to } 21.2 \%)^{48}$. For this reason, $27.2 \%$ of the Ich - AG entrepreneurs take further measures to improve their financial situation. Support from the entrepreneur's own family is the dominating factor here $(18.8 \%)$. The typical Ich $\mathrm{AG}$ of the Hannover region is likewise a one person business ${ }^{49}$. In this study, small businesses not entered into the trade register dominated $(70.2 \%)$. The proportion of freelancers is high $(27.7 \%)$. The Hannover survey also points to low capital requirements for founders: $20 \%$ had no capital requirements and $62 \%$ needed 5,000 Euros or less ${ }^{50}$. Where capital was required, this requirement could be met in virtually all cases without foreign capital $(93.8 \%)^{51}$.

Founding qualifications and qualification strategies

The results of the investigation conducted by G.I.B/IfM have limited use, as those surveyed were taken from a so-called "G.I.B. founders circle" and had therefore shown an interest in foundation qualifications. However, the use of public advisory services, and especially professional associations, was low even among this group ${ }^{52}$. If the utilisation of a business plan is considered specifically as a means to judge founders' qualifications, a notable deficit can be seen within this group. Only every other participant was in possession of a written business plan, “... of which again barely two thirds had been subject to an assessment" ${ }^{\prime 5}$. The BfE study also shows that only a minority had created a written business plan (36.5\%), and that half thereof had not made use of any outside help $(59.4 \%)^{54}$. In the pre-founding planning phases, most of the information the founders surveyed by the BfE required

\footnotetext{
${ }^{47}$ To the question: "In terms of expertise, does your self-employment relate to your previous field of employment?" $52.3 \%$ answered with "Yes", $25.4 \%$ with "Partially" and 22.3\% with "No" or "None". Cf. Büro für Existenzgründungen (BfE), 2004, p. 32 .

48 cf. Büro für Existenzgründungen (BfE), 2004, p. 29.

$4997.9 \%$ of Ich-AG have no full-time employees, $89.6 \%$ of these businesses also have no part-time staff. Source: Wuttke, 2004, p. 92 .

50 cf. Wuttke, 2004, p. 84.

51 cf. Wuttke, 2004, p. 87.

52 cf. Kleinen, H./May-Strobl, E./Suprinovic, O./Wolter, H.-J, 2004, p. $16 f$.

53 Kleinen, H./May-Strobl, E./Suprinovic, O./Wolter, H.-J, 2004, p. 17.

54 cf. Büro für Existenzgründungen (BfE), 2004, p. 27.
} 
concerned matters of taxation and questions regarding the financial services rendered by the employment agency $(72.5 \%$ and $71.7 \%$ ). Significantly fewer than half of the founders stated a need for information regarding areas of business administration incl. financing, the market and competition. In contrast to the G.I.B./IfM survey, the BfE investigation demonstrated that advisory meetings at the employment agency represented the key source of information for founders, followed by correspondence with the BfE itself and the professional associations. $28.6 \%$ of those questioned attended foundation seminars. The proportion of participants which made use of these possibilities and judged them to be only partially useful or not useful at all was high (approx. $44 \%)^{55}$. Nevertheless, estimates on the level of participants' own preparation are high: "Four out of five of those questioned are of the opinion that they were well prepared for self-employment" 56 . The group of Ich AG entrepreneurs in the Hannover region did not engage in extensive preparation. For the majority $(48.9 \%)$, the time span between active planning and preparation lay between one and three months. Almost $30 \%$ of the Ich - AG entrepreneurs completed preparation in even less than a month ${ }^{57}$. However, around two thirds of Ich - AG founders in the Hannover region took advantage of advisory services, while only $39.6 \%$ created a business concept $t^{58}$.

\section{The new self-employed and the founding boom: preliminary conclusions}

When compared to other industrial nations, Germany is not an entrepreneur-oriented country. Nevertheless, various processes of transformation can be observed in this field which promote varying forms of entrepreneurial thinking and action. A fundamental aspect of socio-economic development involves supplementing or replacing "planning/organisation" with "competition". This in turn opens up new arenas of competition with free space for self-employment in different forms, and for entrepreneurial thinking and action. The increase in self-employment in Germany has, however, been markedly influenced by labour market policy measures as the Ich - AG. The number of Ich - AG start-ups rose by $120 \%$ in the period between January 2004 and January 2005 alone. If empirical findings are also considered, it is clear that the overwhelming majority

\footnotetext{
55 cf. Büro für Existenzgründungen (BfE), 2004, p. 24f.

56 Büro für Existenzgründungen (BfE), 2004, p. 27.

cf. Wuttke, 2004, p. 74

58 cf. Wuttke, 2004, p. 75 and p. 77.
}

of the new self-employed come out of unemployment which, in most cases, lasted over a year. The chief motivational factor for those who found Ich - AGs is the return to a state of employment. In the clear majority of cases, business founders are German citizens with an average age of 40 living in a multiple person household. Women start businesses at a similar rate to men. Ich - AGs are dominated by one-person businesses. The Ich - AG grant is, on average, estimated as constituting less than the unemployment benefit previously received ${ }^{59}$. For Ich - AG business founders with families, the income earned from the business founded is not usually the only source of income. The new self-employed are for the most part engaged in the services sector, partly also in the field of freelance work. Businesses involved in production represent a minority. This choice of sector results in relatively low capital requirements, generally under 5,000 Euros. The majority of business founders investigated had completed a course of vocational training, and about two thirds even an academic degree. Persons who had failed to complete general and vocational education were exceptions. Nevertheless, knowledge of commercial sectors or vocational experience gained before the founding of the Ich - AG tended not to play a large role when deciding in which sector the Ich - AG should operate often a new sector different to the one experienced is chosen. Looking at the demand for advisory services, the Ich - AG business founders require relatively little in terms of qualifications or advice, particularly concerning business administrative questions relevant to the business founded. Qualification courses are not considered by business founders as being relevant for success. Failure to utilise vocational experience in a sector, the strong reluctance to seek qualifications and engage in preparation for the new business and deficient analysis of product/market concepts is astonishing for a group whose educational and vocational records demonstrate the desire to achieve high-level (formal) qualifications. If preparation time and the creation of written plans are considered, clear deficits are evident. The Ich - AG entrepreneur generally has no business plan $^{60}$ and takes little time to prepare his or her enterprise.

When Ich - AG founders and their motivations are considered, neither correspond to the common conception of entrepreneurs and entrepreneurship, in

\footnotetext{
59 However, the investigations were undertaken before the combining of unemployment and social benefits and possible cutbacks resultant of legislative changes (so-called Hartz IV laws).

${ }^{60}$ It should however be taken into consideration that the investigations were conducted prior to relevant legislative changes.
} 
terms of the latter representing the imagination, development and realisation of one's own goals and visions in an environment determined by competition ${ }^{61}$ [18]. In place of the innovative, vision-driven entrepreneur, the dominant group of Ich - AG business founders are the unemployed who see starting a business as a realistic possibility to escape unemployment. Alternative, conventional employment would be preferred by a large portion of this group - without support, financial or otherwise, from the state, they would not have entered self-employment. The "Global Entrepreneurship Monitor" (GEM) study designates this type the "Necessity Entrepreneur". He or she founds a business because there is no other adequate alternative. This is contrasted to the "Opportunity Entrepreneur" who starts a business in order to economically exploit a business idea ${ }^{62}$. The Global Entrepreneurship Monitor's country report for Germany verifies that the relative importance of "Necessity Entrepreneurship" has significantly and continually increased $^{63}$, in eastern Germany more strongly than in the $\mathrm{West}^{64}$. Although Ich - AG business founders do not correspond to the conventional ideal of the dynamic, innovative entrepreneur, neither do they represent the stereotyped transformation loser (poorly qualified and lacking vocational skills, background of migration etc.).

A final assessment of the Ich - AG's economic success is not yet possible. The future will tell whether the new self-employed prosper. Initial prognoses concerning the long term economic viability of Ich AGs are rather sceptical: only half of all businesses started will survive the three year time period during which the start-up grant is paid ${ }^{65}$ [19]. Between January 2003 and spring 2005 over a quarter of a million Ich - AGs have been supported with the business grant. Almost a fifth thereof no longer receive the grant, although it is offered for up to three years ${ }^{66}$ [20]. As far as is evident from initial findings, the majority of failed Ich - AG entrepreneurs (the proportion of Ich - AG business founders who give up while the grant is still being paid) fall back into unemployment (Fig 5).

To provide a concluding summary, it can be seen that state-sponsored financial support for the founding of new businesses has triggered a start-up boom in Germany. Initially findings, however, reveal the fact

${ }^{61}$ cf. Julien, P.-A., 1998, p. 139.

${ }_{62}$ cf. Sternberg/Lückgen, 2005, p. 16.

63 cf. ibid, p. 50.

64 cf. ibid, p. 16.

65 Treiber, 2005.

66 Wießner, 2005.

\begin{tabular}{|c|c|}
\hline Situation after the Ich - AG & Proportion in \% \\
\hline $\begin{array}{c}\text { Unemployed receiving } \\
\text { unemployment benefit }\end{array}$ & 51,6 \\
\hline $\begin{array}{c}\text { Unemployed receiving no } \\
\text { unemployment benefit }\end{array}$ & 2,0 \\
\hline $\begin{array}{c}\text { Employed and obliged to contribute } \\
\text { to social insurance }\end{array}$ & 33,6 \\
\hline Employed in another form & 2,2 \\
\hline $\begin{array}{c}\text { Other, non-supported self- } \\
\text { employment }\end{array}$ & 4,5 \\
\hline Further education/Re-training etc. & 1,4 \\
\hline Maternity leave/parental leave & 0,8 \\
\hline Retired/Early retirement & 0,5 \\
\hline Other & 3,4 \\
\hline
\end{tabular}

$\mathrm{n}=643$ (Survey conducted in the second quarter of 2004) Source: Wießner, 2005.

Fig 5. Consequences for failed Ich - AG founders

that that the motivations, starting points and actions of a considerable proportion of the new self-employed tend to preclude their classification as entrepreneurs. In autumn 2005, the mediation committee of the German Bundestag (the lower house of parliament) elected to phase out support for Ich - AGs. If this parliamentary decision remains unchanged after the general election on the 18 . September 2005 it is highly probable that the portion of the start-up boom triggered by labour market policy measures will collapse. Nevertheless, it cannot be ruled out that in the long term, economic and social changes concerning structure and mentality in Germany will result in a sustained increase in self-employment relative to the present situation.

\section{References}

1. http://www.destatis.de/basis/d/vgr/vgrtab1.php

2. Hartmann, M. Die Entwicklung des Arbeitsmarktes im April 2005. In arbeit und beruf 6/2005, p. 166-169.

3. http://www.arbeitsagentur.de/vam/vamController/ CMSConversation/ anzeigeContent docId $=78930 \& \mathrm{rqc}=5 \& 1 \mathrm{~s}=$ false $\& u t=0$

4. Statistisches Bundesamt: Statistisches Jahrbuch 2004 für die Bundesrepublik Deutschland. Wiesbaden, 2004.

5. Statistisches Bundesamt: GESIS. Wiesbaden, 2003.

6. Biersack, W.; Parmentier, K.; Schreyer, F. Berufe im Spiegel der Statistik. In: Institut für Arbeitsmarkt- und Berufsforschung (Ed.): Beiträge zur Arbeitsmarkt- und Berufsforschung, Bd. 60. Nuremberg, 2000.

7. Sternberg, R.; Lückgen, I.: Global Entrepreneurship Monitor - Länderbericht Deutschland. Köln, 2005. 
8. Presse- und Informationsamt der Bundesregierung (Hrsg.): agenda 2010 Deutschland bewegt sich. Berlin, February 2004.

9. Institut für Arbeits- und Berufsforschung: "Moderne Dienstleistungen am Arbeitsmarkt." Stellungnahme des IAB zum Bericht der Hartz - Kommission. Diskussionsbeiträge Nr. 13. Nürnberg 1.10.2002.

10. Bundesministerium für Wirtschaft und Arbeit (Hrsg.): Ich - AG und andere Kleingründungen, 4. Auflage. O.O. December 2004, p. 18.

11. KfW Bankengruppe (Hrsg.). KfW Gründungsmonitor, 2004. Frankfurt, 2004.

12. Bundesagentur für Arbeit: Monatsbericht Januar 05 . Nürnberg, 2005.

13. Bürgschaftsbank zu Berlin-Brandenburg: Gründerindex, Hintergrundinformation. Berlin, 01/2005.

14. Zentrum für Europäische Wirtschaftsforschung: ZEW Gründungsreport Nr. 2. O.O. November 2004.

15. Kleinen, H.; May-Strobl, E.; Suprinovic, O.; Wolter, H.-J. Ich-AG und Überbrückungsgeld. Eine empirische Analyse von Gründungen aus der Arbeitslosigkeit. In: Gesellschaft für innovative Beschäftigungsförderung mbH (G.I.B) (Hrsg.): Arbeitspapiere 12. Essen, 2004.

16. Wuttke, J. Warum Gründer scheitern - eine empirische Analyse der Erfolgs- und Überlebenswahrscheinlichkeit von geförderten Gründern aus der Arbeitslosigkeit. Diplomarbeit Fachhochschule Hannover/Rodenberg 2004.

17. Büro für Existenzgründungen (BfE): Perspektive Selbstständigkeit - BfE-Studie zu Ich-AG-Gründungen 2003. München, 2004.

18. Julien, P.-A. The State of the Art in Small Business and Entrepreneurship. Aldershot, 1998.

19. Treiber, M.: Prognose der Überlebenswahrscheinlichkeit von Ich - AG's nach drei Jahren.

www.ueberbrueckungsgeld.de/service/pressemitteilung/ ichAG.pdf. 03.02.2005

20. Wießner, F. Neues von der Ich - AG: nicht jeder Abbruch ist eine Pleite. In: Aktuelle Analysen aus dem Institut für Arbeitsmarkt- und Berufsforschung der Bundesanstalt für Arbeit. Ausgabe Nr. 2/2005 